\title{
Achievement Supervision Management on Indonesian Futsal Club (IFC)
}

\author{
Herman \\ Universitas Negeri Makassar \\ Makassar, Indonesia
}

\author{
Hasyim \\ Universitas Negeri Makassar \\ Makassar, Indonesia
}

\begin{abstract}
The openly and synergy management of achievement supervision for athletes is an asset for success and promote the organisation. This study aims to determine the description of the achievement of planning, organising, leadership, evaluation and monitoring in the futsal club supervision. This type of research is a descriptive method. Data analysis technique used is the percentage technique. The results showed that the management achievement of planning, organising, and leadership was in a good category. However, monitoring and evaluation management of futsal club supervision was in the average category.
\end{abstract}

Keywords - supervision; management; futsal

\section{INTRODUCTION}

The improvement of the needs of human behaviours about the improvement of human health and education that has been provided by the education institutions should support the sustainable development concepts. The concept gives all the human resources ability to sustain their quality of their environment, the idea of sustainable development in this case related to the social and economic issue, and ecological aspect to provide the next generation value of life [1]. Moreover, the sustainable development is also boosting the human resources to improve their community livelihoods. This concept also enhances the knowledge of the community and creates the community value to support the change in the social relationship [2]. This shift enhances the awareness of the community supports the human resources globally. This is related to the promotion of the organisation management to promote the achievements of the needs of the athletes.

Implementing the openly and synergy management in achievement supervision of athletes requires a high anticipation due to an asset for success and promote the organisation, especially for futsal. Hence, it takes the role of a manager, a reliable trainer to pay attention to the achievements of athletes as well as futsal [3]-[7]. These efforts should be carried out jointly to achieve optimal athletic performance [8].

To support the performance of the organisation as a means to achieve a goal, especially for futsal club to raise the achievement that is currently in bad condition. Therefore, sports organisations should meet several key conditions, namely the administrator who has a foundation of togetherness, high loyalty to the organisation goals and always strive to uphold the rules of the organisation [9]. However, the most important aspect to be considered is the implementation of management functions including planning, organising, leadership as well as the evaluation and supervision of the organisation.

Sports organisations, especially for futsal club organisation has its characteristics according to its nature. The big problem that is frequently encountered in the organisation is the management of supervision, which is unfocused based on the appropriate needs and goals of the organisation leading to inefficient and ineffective performance [10]. Achievement of futsal club begins to decrease due to poor management; the futsal management is lacking planning-related aspects of setting goals and objectives. The management also is lack of identifying recruitment of athletes, the draft of the work program, and designing supervision. The condition requires organising the related aspects of work planning, establish mechanisms of work, responsibility in advancing the organisation and administration of tasks and jobs. However, the highest decision making related to leadership in mobilising and directing the organisation to achieve organisational objectives and evaluation as well as supervision providing accurate information about the success of achievement supervision.

\section{METHOD}

The researchers used quantitative descriptive research by conducting survey [11] that focus on management functions in achievement supervision of futsal club. The researchers used convenient technique sampling for ease access of population [12]. The researchers researched Futsal club around the Makassar city, South Sulawesi, Indonesia.

The research instruments to measure the variables in this study were in the form of observation checklist and questionnaire. Observation includes activities focusing on an object by using all the senses and questionnaires covering some written questions that were used to obtain information from the respondents in the sense of personal statements, or required information using Likert scale format.

\section{RESULTS}

Figure 1 below provides information on an average score of achievement supervision management on Indonesian Futsal Club. This section describes the achievement supervision management including planning, organisation, leadership, and monitoring in Indonesian Futsal Club. 


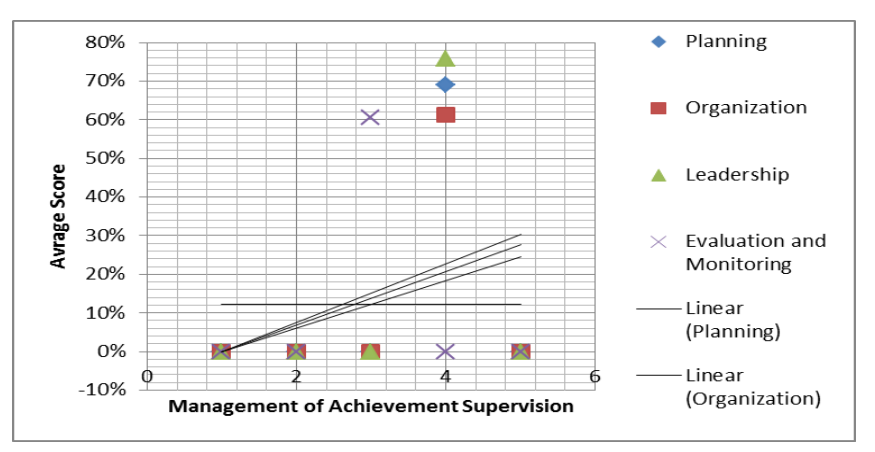

Fig. 1. The average score of achievement supervision management on Indonesian Futsal Club.

\section{A. Planning}

The above Figure 1 showed the average score based on the questionnaire data of planning management for supervision of Futsal club achievement. Based on this data, the policy makers considered this data to establish the targeted aspects and objectives, identified the athlete recruitment, programmed the draft work, and designed the supervision. The average score of implementing the aspects of goal setting goals and objectives, identifying recruitment of athletes, drafting the work program, and designing supervision was $69.04 \%$. This was in line with the assessment intervals of $61 \%-80 \%$ that was in good category.

\section{B. Organization}

Figure 1 above indicated the average score of the questionnaire on organisation management of achievement supervision. This questionnaire consisted of the designed work program, established work mechanism, was responsible for advancing the work, determine the mechanism of action, responsibility in promoting the organisation, and distributed duties and work. This section consisted of designed work, established the working mechanism, and was responsible for advancing the organisation and distribution of rights and works. The average score for this section was $61.33 \%$ that was in $61 \%-80 \%$ of assessment intervals, which was in the good category. This section consisted of designed work, established work mechanism, was responsible for advancing the organisation and distributed the duties and works.

\section{Leadership}

Figure 3 above showed the average score of the questionnaire on leadership management of achievement supervision of Futsal club. This section consisted of leadership style, decision-making and motivation to manage. The average score of leadership management was shown in Figure 1 above that was implemented based on the aspect of the direction style, decision-making and motivation to manage. The average of overall these items were 76.72 , which within $61 \%-80 \%$ to indicate the good category.

\section{Monitoring}

The average score of the questionnaire of control and evaluation management for achievement supervision was analysed based on the aspect of success supervision, monitoring the development activities, the implementation of the evaluation system, and measurement of work. Based on Figure 1 above, the average score was $60.60 \%$ that was in the average category.

\section{DISCUSSION}

A series of goals planning begins with the decision about the desire needs of the organisation or work group to formulate the current situation by analysing the present situation was in a good category. Hence, the stakeholders could consider the future circumstances [13]. In identifying the ease and constraints, we could use the method of Strength, Weakness, Opportunity, and Treats (SWOT) [14]. The organisation needs to be identified to measure the organisation's ability to achieve the goal of developing a plan for goal achievement. The last stage of the planning process needs to be a variety of alternative assessment and decisionmaking to determine the best choice among alternatives of the policy to increase the achievement the Indonesian Futsal club.

Management of organisation data on achievement supervision of Indonesian Futsal club analysed from designing aspects of the work, establishing the mechanism of work, being responsible for advancing the organisation and distributing the duties and works. The organization is done with the aim of sharing a great activity into the activities of smaller ones. Organization management facilitates managers in monitoring and determining those required to carry out the tasks [3]. Organization management can be done by determining kinds of tasks, the person in charge, and the group classification. How the tasks are grouped, who is responsible for the task, at which level decisions should be taken. The function of the organization includes the formulation of clear goals, the division of work duties delegated authority containing a coordination mechanism. Improved performance is required in organising the achievement supervision of Indonesian Futsal club.

The manager has well-implemented leadership style based on the response measured within each organisation [15], [16]. This study showed the development, so leadership aspect needs an immediate response. Decision-making is done to motivate administrators, coaches and athletes, such as the maximum reward for these things can add to the work ethic administrators, coaches and athletes in carrying out the tasks given to the organisation's goals [17]. Directing managers to do an activity in the management associated by providing guidance, advice, motivation, assignment, orders, or instructions to subordinates. Indeed, the leadership stiyle is expected to carry out works in achieving the objectives set in the purpose of the organisation. In this study, the data showed that leaders are directing certain tasks by creating the right atmosphere. Leaders help their subordinates to work as best as possible. Preparation of staff aimed at obtaining skilled labour in the right amount. Staffing functions about training, development and placement and orientation provision of the employees in the work environment.

Monitoring and evaluation have been moving towards the desired objectives. Therefore, it is necessary to control periodically and continuously by a leader to improve the 
achievement of Indonesian Futsal club. Control is a series of surveillance that work is progressing by a predetermined plan. There are several steps in the control process is establishing standards and methods to measure achievement, measure performance, compare whether performance conforms with the standards specified, taking corrective action or improvement. We must empower organisations in professional sports. To enhancing the achievements made by the Indonesian Futsal club already refers to the practice of appropriate management in performance sports of national Futsal club cultivated [5]. However, the implementation is expected to support the achievement of the futsal sport cultivated in facing the competition on sporting events either in regional and national or international level.

\section{CONCLUSION}

This study recommends to the board of Indonesian Futsal club to be able to explore and apply management planning, management, organisation, leadership management and monitoring and evaluation administration of the achievements supervision. This study suggested to implement good sports management into a learning organisation and to apply science and technology sport consistently and consequently in supervision programs and the implementation of the training program. The Indonesian Futsal club still needs to try out the island of neighbouring countries, and they need facilities and infrastructure such as Gym fixed to use athletes as weight training to improve and maintain the physical condition.

\section{REFERENCES}

[1] S. Nurfaizah, W. Thalib, Asmawati, and G. D. Dirawan, "Effect of knowledge and reproductive health of family planning family planning program participation in fertile age women poor families in the city Makassar," Man India, vol. 95, no. 3, pp. 695-701, 2015.

[2] A. Juhanto and G. D. Dirawan, "Knowledge, attitudes, and behaviors students in the prevention of HIV/AIDS in senior High School i South Pamona district poso in Central Sulawesi," Man India, vol. 95, no. 3, pp. 715-726, 2015.

[3] T. Anchieta, "Management Sports In Entities of Administration of Sport: a restructuring plan for Amazonense Federation of Futsal," Oral Sess., p. 272.

[4] Q. Lewei, H. Deyi, and W. Zhiqin, "Studies of Development of Futsal League in Guangdong-Take Pearl Super League and Guangdong Super League as example," 2013.

[5] D. Cosmin and N. Mircea, "The development of futsal game at national level by implementing a strategic competitive and training management," Ovidius Univ. Ann. Ser. Phys. Educ. Sport. Mov. Heal., vol. 14 , no. 2, pp. 376-381, 2014.

[6] R. Kural, "Changing spaces for sports 1," Sport Soc., vol. 13, no. 2, pp. 300-313, 2010.

[7] R. Moore, S. Bullough, S. Goldsmith, and L. Edmondson, "A systematic review of futsal literature," Am. J. Sport. Sci. Med., vol. 2, no. 3, pp. 108-116, 2014.

[8] D. Nikbin, S. S. Hyun, M. Iranmanesh, and B. Foroughi, "Effects of Perceived Justice for Coaches on Athletes' Trust, Commitment, and Perceived Performance: A Study of Futsal and Volleyball Players," Int. J. Sports Sci. Coach., vol. 9, no. 4, pp. 561-578, 2014.

[9] J. Borgers, J. Seghers, and J. Scheerder, "Organizational settings for youth sports participation," Routledge Handb. Youth Sport, p. 158, 2016.
[10] E. Sherry, N. Schulenkorf, and P. Phillips, Managing Sport Development: An International Approach. Routledge, 2016.

[11] F. J. Fowler Jr, Survey research methods. Sage publications, 2013.

[12] J. J. Castillo, "Convenience sampling," Retrieved Oct., vol. 2, p. 2013, 2009.

[13] D. Miragaia, M. Brito, and J. Ferreira, "The Role of Stakeholders in the Efficiency of Nonprofit Sports Clubs," Nonprofit Manag. Leadersh., 2016.

[14] W. Lu, H. Li, L. Shen, and T. Huang, "Strengths, weaknesses, opportunities, and threats analysis of Chinese construction companies in the global market," J. Manag. Eng., vol. 25, no. 4, pp. 166-176, 2009.

[15] A. R. Gomes, A. P. Pereira, and A. R. Pinheiro, "Leadership, cohesion and satisfaction in sporting teams: a study with Portuguese football and futsal athletes," Psicol. Reflex. e Crit., vol. 21, no. 3, pp. 482-491, 2008.

[16] A. R. Gomes and R. Resende, "Assessing leadership styles of coaches and testing the augmentation effect in sport," Contemp. Top. trends Psychol. Sport., pp. 115-137, 2014.

[17] A. Tumbelaka, P. Kindangen, and F. J. Tumewu, "Customer Decision Making In Selecting Futsal Court In Manado In Terms of Perceived Quality: As Application of Analytical Hierarchy Process (AHP)," J. Ris. Ekon. Manajemen, Bisnis, dan Akuntasi, vol. 3, no. 3, 2015. 